\title{
Dictynna
}

Dictynna

Revue de poétique latine

5 | 2008

Varia

\section{The Six Books of Lucretius' De rerum natura: Antecedents and Influence}

Joseph Farrell

\section{(2) OpenEdition}

1 Journals

\section{Electronic version}

URL: http://journals.openedition.org/dictynna/385

DOI: $10.4000 /$ dictynna.385

ISSN: 1765-3142

\section{Electronic reference}

Joseph Farrell, «The Six Books of Lucretius' De rerum natura: Antecedents and Influence », Dictynna [Online], 5 | 2008, Online since 25 November 2010, connection on 10 September 2020. URL : http:// journals.openedition.org/dictynna/385; DOI : https://doi.org/10.4000/dictynna.385

This text was automatically generated on 10 September 2020 .

\section{(c) $(1) \Theta \Theta$}

Les contenus des la revue Dictynna sont mis à disposition selon les termes de la Licence Creative Commons Attribution - Pas d'Utilisation Commerciale - Pas de Modification 4.0 International. 


\title{
The Six Books of Lucretius' De rerum natura: Antecedents and Influence
}

\author{
Joseph Farrell
}

The structure of Lucretius' De rerum natura is generally considered one of the poem's better-understood aspects. For most critics, poetic structure is the servant of Lucretius' philosophical argument. In general, that argument proceeds in linear fashion from discussion of the simplest components of the universe to analysis of complex and unusual phenomena. This linear structure involves three distinct stages comprising two books each. Broadly speaking, these stages concern the existence and behavior of atoms and void individually and in combination (books 1-2), the material nature of the soul (books 3-4), and the origin and development of human societies (books 5-6). At the same time, on a slightly higher plane of abstraction, the poem can be understood as falling into halves, the first three books dealing with the basic principles of atomic theory and the latter three with the ethical implications of the theory. These two overlapping arrangements $(2+2+2$ and $3+3)$ both support the overall argument of the poem by stressing its clarity and orderly progression, and by giving discursive form to the interrelationship between its several parts. ${ }^{1}$

But however well the structure of DRN serves Lucretius' argument, it was not dictated by that argument itself. From a purely expository point of view, other arrangements could have served just as well. ${ }^{2}$ Nor was a six-book structure recommended by Lucretius' philosophical sources. Indeed, compositions in prose or poetry comprising six distinct "movements" are rather unusual in classical literature. Among such works, the combination of binary $(3+3)$ and ternary $(2+2+2)$ structures within existing sixelement designs is rarer still. This means that specific structural models or even antecedents for the Lucretius' poem are hard to find, as are later compositions modeled in turn on DRN. ${ }^{3}$

3 With all of this in mind, I attempt in this paper to account for the distinctive structure of Lucretius' poem by looking for similar structures in the work of his predecessors and successors. My concern is with the significance of the poem's six-book structure when we view it in terms of literary history. Do Lucretius' six books look back to any specific 
model (or models), placing the poem within an identifiable literary tradition, and do they establish a pattern for later poets to follow? The answer, I think, is that Lucretius' poem stands at the center of a quite interesting, if select tradition of Greco-Roman poetry. This tradition begins with two poets, Callimachus and Ennius, who I believe supplied Lucretius with the characteristic elements of his six-book design. It continues with Ovid, who clearly acknowledges, through its structure of the Fasti and through other allusive gestures, that poem's debt his debt to Lucretius and to Callimachus and Ennius as well. ${ }^{4}$ I would suggest in addition that Lucretius' combination of the methods for dividing a six-part ensemble that he found in Callimachus and Ennius - the binary pattern in the latter and the ternary pattern in the former - are a token of his influence not only on Ovid but also on Augustan poets more generally.

The Callimachean work in question is the collection of Hymns. These form not a multibook corpus but a single book containing six poems. The manuscript tradition transmits them in an order, which Pfeiffer believed originated with Callimachus and that clearly reflects an artistic arrangement of three pairs. ${ }^{5}$ The first two hymns are mimetic, have single male subjects (Zeus and Apollo), and are the shortest poems in the collection (96 and 113 lines). The next two (Artemis and Delos) are narrative; both have the twins Artemis and Apollo as their subject, and are the longest poems in the collection (268 and 326 lines). Hymns 5 and 6 (Baths of Pallas and Demeter) are again mimetic, have female subjects, and in length fall between the extremes established by the first two pairs (142 and 138 lines). The last two hymns are further linked by being in the Doric dialect, while the first four hymns are in Epic/Ionic. The design of the book, then, is quite obviously based on three pairs of adjacent hymns. The arrangement is predominantly symmetrical (two pairs of short, "mimetic" poems surround two longer, narrative ones), but it involves elements of progression as well (movement from male to mixed to female addressees; from Ionic to Doric dialect; the introduction of a new meter, elegiac couplets, in poem 5).

These formal elements make the book of Hymns at least a forerunner, and perhaps a specific model, for Lucretius' decision to structure DRN as three groups of two books each. Additional similarities strengthen this possibility.

Most obviously, several books of Lucretius' poem begin with a hymn. ${ }^{6}$ The specific addressees of Lucretius' hymns - Venus in book 1, Epicurus in book 3 and 5, Athens in book 6 - do not, of course, correspond with those of Callimachus.But the fact that Lucretius uses the hymnic form at all in a poem dedicated to convincing the reader that traditional religious beliefs are mistaken is remarkable and has occasioned much discussion. ${ }^{7}$ One motive for using this form so prominently may be to indicate a literary debt to Callimachus' Hymns as a structural model for Lucretius' poem.

7 It is also the case that Callimachus' design puts a certain emphasis on the central two hymns of the collection. It achieves this effect by placing the two longest hymns in the central position. In DRN the length of individual books is more variable, while each successive pair of books is longer than the one that precedes it. ${ }^{8}$ But Epicurus' doctrine of the soul is in many ways the essential point of Lucretius' poem. The elemental doctrines of books 1-2 precede it logically, and the social and anthropological discussions of books 5-6 follow from it. But the sheer fact that human soul is mortal and that we therefore have nothing to fear from death - is Lucretius' paramount concern, and his proof of this doctrine receives great emphasis from its central position in books 3 and $4 .{ }^{9}$ It may be that Lucretius' decision to emphasize this point by placing 
it in this central position was partly inspired by Callimachus' making his two longest and most ambitious hymns the centerpiece of a six-element design.

8 I shall return to Callimachus, but at this point let us turn to consider the other inspiration for Lucretius' six-book design. In book 1 of DRN Lucretius famously and programmatically cites Ennius noster in such a way as to declare that his poem will be Ennian in form if not in content. ${ }^{10}$ The gesture is usually interpreted as a reference to the Ennian phrases and metrical effects with which the poem is liberally endowed. But it would not be surprising if some additional aspect of the poem's formal design also derived from Ennius.

9 What then about the structure of the Annales? On a few points, there is fairly general agreement. In the Annales, book-divisions were for the first time in Latin poetry part of the author's artistic design. ${ }^{11}$ Almost certainly groups of three books formed another, higher-level structural unit. ${ }^{12}$ But while these aspects of the poem's structure can be regarded as definite or nearly so, others remain a puzzle. The chief problem is that the Annales evidently existed as a corpus of fifteen books for some period of time. ${ }^{13}$ Ennius then added new books to the existing poem, eventually bringing it to a total of eighteen. ${ }^{14}$ Accordingly, it is unclear how to assess the poem as a unified design. Most scholars currently focus on books 1-15 as the most fully realized, unified instantiation of Ennius' ambitions and regard books $16-18$ as an essentially different work that may even have circulated separately. ${ }^{15}$ The question of what form of the Annales best and most fully reflected Ennius' intentions (and whether we mean his original or his final intentions) is too large and too theoretically murky to go into here ${ }^{16}$ But fortunately, there is no need to do so. For our purposes, the important point is not how Ennius structured his poem, but how readers, and especially Lucretius, understood its structure. Lucretius was certainly in a better position than we are to make this sort of judgment. He had vastly more of the poem than the scraps that are left to us. We may presume that he knew the entire Annales, including books $16-18 .{ }^{17}$ But in one sense, Lucretius was in no different a position from our own. The architectural design of any poem depends on decisions made by its author, but the perception of that (or of any other) design is a matter of readerly interpretation. The proem to book 16, which makes it clear that Ennius has returned to the Annales after a period of some years, might have led Lucretius (as it has many modern scholars) to regard everything that followed as extraneous to Ennius' original design. On the other hand, having before him a single, eighteen-book corpus, Lucretius may (like other scholars) simply have tried to make sense of the Annales as a unified composition in eighteen books. If he did so, what will have been the result?

10 Most books of the Annales are so fragmentary that we cannot say in total confidence what features may have served to articulate the poem's internal structure. But we do know that books 1 and 7 both began with major proems that were famously influential in antiquity-not least on Lucretius..$^{18}$ Johannes Vahlen assumed that every book of the Annales began with a formal proem of some sort, even if they were not all as ambitious as those of 1 and $7 .{ }^{19}$ But at least one book seems to have plunged right into narrative. ${ }^{20}$ So it makes sense to assume, as the majority of scholars have done, that proems were reserved for some special effect or other. It would be consonant with earlier Greek and later Roman practice if such proems served to introduce major points of articulation in the poem's design. Given a poem in eighteen books with major proems in books 1 and 7, a knowledgeable reader ancient or modern might infer the existence of a tripartite 
structure based on groups of six books (hexads). This impression would be strengthened if there were a similar proem in book 13 as well, but unfortunately we have no evidence either way.

11 Were there other proems? Some of the evidence is equivocal. ${ }^{21}$ It does seem likely, though, that books 10 and 16 began with formal proems. The impression gained from the ancient reception of these proems is that they were less grand than those of books 1 and 7 , and this suggests that they played some lesser role than what I have suggested for those. Two obvious possibilities present themselves. In the first place, books 10 and 16 both begin new triads, and it may be that all such books featured proems that will have reinforced the reader's sense of the poem's structure at that level. Such a system could have worked together with the distribution of more ambitious proems in 1, 7, and perhaps 13 to create a clear sense of a two-tiered structure of triads and hexads. If this is the case, or even if it is not, more can be said about these books in particular. The years that had evidently lapsed since the composition of books 15 and 16 and the opportunity to compare the wars of the present to those of the past may (in Ennius' judgment) have called for a more ample and reflective proem in book 16 than did the beginnings of other triads. Book 10 is also a special case, not least because it evidently began with a new invocation of the Muses. ${ }^{22}$ As such, it would seem to exemplify the phenomenon that Gian Biagio Conte has dubbed the "proem in the middle" if assessed in the context of an eighteen-book design. ${ }^{23}$

of course none of this is at all conclusive, particularly regarding Ennius' own design of the Annales. But it does indicate how readers of the complete poem in eighteen books might have understood its design. And for Lucretius in particular, several elements of the design that I have sketched could have been interesting.

To begin with, there is the relationship of triads and hexads within this design. We have seen that the idea of structuring $D R N$ as a sequence of three pairs of books is congruent with the design of Callimachus' Hymns. But that work shows no sign of a bipartite organization. Most scholars agree, however, that three-book units (triads) are an important element in the design of the Annales. And, as we have seen, the poem contains gestures that might encourage readers to group adjacent triads into coherent hexads $(1-3+4-6,7-9+10-12$, etc.) This is congruent with the other major organizational scheme of DRN. Adoption of this scheme could thus be an element of Lucretius' Ennian imitatio.

14 There might be additional reasons why Lucretius would invite the reader to consider his poem as an Ennian hexad. For instance, while Ennius certainly remains Lucretius' principal model in Latin poetry - the only one that he cites by name - alongside Ennius he cites Homer. Just as in Ennius' own conceit, Lucretius' greatest Greek and Roman predecessors are almost fused together into a single personality. If we imagine the structure of $D R N$ as alluding in some way to this fusion, then the decision to divide the poem into six books makes additional sense, in the following way: Lucretius' six books may be regarded as "completing" Ennius' Homeric imitatio by rounding out the number of books in the Annales, eighteen, to the number of books in either of the Homeric poems, twenty-four. Some corroboration for this idea may come from Vergil's treatment of Homer in the Georgics and the Aeneid. Vergil's epic, as everyone knows, combines more or less all of the Iliad and the Odyssey into twelve books, half the number of a single Homeric epic. But Llewelyn Morgan has made the very clever suggestion that Vergil's treatment of book 4 of the Odyssey in book 4 of the Georgics allows the 
reader of the Aeneid to regard the earlier poem as the Telemachian prelude to the latter. ${ }^{24}$ Something not entirely dissimilar may be at work if Lucretius' six books are intended to complete Ennius' eighteen. It would also be consonant with the dominant aesthetic principles of Lucretius' day if he were in effect boasting that he could accomplish his own Homeric agon in the space of only six books, while Ennius had required three times as many. ${ }^{25}$

How do these observations concerning Ennius comport with our earlier argument concerning Callimachus? As we have seen, by structuring the six books of DRN as three pairs of books, Lucretius may have been inspired by Callimachus' arrangement of his Hymns. ${ }^{26} \mathrm{But}$ by incorporating a different structure not found in Callimachus, one based on two groups of three books, Lucretius may have been overlaying his Callimachean structure with that of an Ennian hexad as well. If we put these results together, we can account for the decision to give $D R N$ a six-book structure and to inform that structure with two mathematical systems, one based on pairs of books $(2+2+2)$ and the other based on triads $(3+3)$. Interestingly, this involves a combination of Callimachean and Ennian structures in ways that are not just formally opportune, but thematically interesting as well. In terms of scale, Lucretius' poem, both in whole and in part, represents a middle way between Callimachean minimalism and Ennian grandiosity. Thematically, Lucretius borrows from a collection of religious hymns and from a historical epic. Again, his own poem rejects the hypostasization either of conventional religiosity or of history as determiners of meaning or as means to salvation. As in other respects, Lucretius' command of the poetic tradition and his admiration for the literary masters of the past does not prevent him from going his own way philosophically. Indeed, his adaptation of these formal elements may serve to underline the distinctive message of his own poem.

In literary-historical terms, the combination of these two models might be seen as a surprising move. But Ennius has been seen as being aware of and even as following Callimachus in some respects. ${ }^{27}$ If this is so, then Ennius' use of Callimachus should have been apparent to at least some ancient readers; certainly to Lucretius, who is himself obviously familiar with and hardly hostile towards some of Callimachus' characteristic literary ideals. ${ }^{28}$ This is not to deny that Callimachus may have acquired a new and more specific significance for some of Lucretius' contemporaries. But even if this is the case, the idea of an unbridgeable gap between the followers of Ennius, including Lucretius, and those of Callimachus, such as Catullus and the "neoterics," has sometimes been greatly overstated..$^{29}$ Even if we suppose that Catullus and a few likeminded poets took an extreme view of these matters, Lucretius need not have joined battle on their terms. And of course these "incompatible" traditions were effectively reconciled in the poetry of the Augustan period. ${ }^{30}$ It would be interesting in light of this later development if Callimachus played such an important role in an expansive Lucretian poetics. Such an example, in contrast to that commonly ascribed to "the neoterics," might help to explain the more eclectic approach of the Augustan poets to earlier poetic traditions.

It is in fact to a notable example of such Augustan eclecticism that I now turn. If there is any poem of the Augustan period that owes important aspects of its structure to that of De rerum natura, that poem is Ovid's Fasti. And what is most interesting about this relationship is that the Fasti not only follows Lucretius' formal approach to the 
structure of a six-book poem, but it does so while remaining fully engaged with both of Lucretius' sources for this design, Callimachus and Ennius.

First the formal considerations. The Fasti as it stands is, like the De rerum natura, a sixbook didactic poem. This fact can easily be overlooked and, until recently, most critics have treated the Fasti not as a complete poem in six books, but as a radically incomplete poem in twelve. Of course, the idea that the Fasti is or ought to be a twelve-book poem is hugely overdetermined. Not only would a twelve-book design allude to that of the Aeneid, a major intertext both in the Fasti and practically everywhere else throughout Ovid's oeuvre, but it is even demanded by the structure of its subject, the twelve-month year of the Roman calendar. Moreover, Ovid insists on twelve as the proper number of books for this poem. ${ }^{31}$ Perhaps understandably, then, the poem's apparently fragmentary and only partially-revised state for a long time inhibited critics from making serious efforts to interpret it as a poetic whole; and under such circumstances, the idea that we are dealing with a poem intended to be complete in twelve books could hardly have encouraged the exploration of any possible parallel with Lucretius' sixbook structure. In recent years, however, critics have increasingly entertained the possibility that Ovid decided at some point to design or redesign the poem as a deliberate fragment, "complete" in six books. ${ }^{32}$ The results have been well received, although the implications of this insight have only begun to be worked out.

For this reason, we may consider whether the six-book Fasti might owe aspects of its structure to DRN. If we do, we find that the internal structure of the Fasti exhibits a number of similarities to that of Lucretius' poem. It remains true that any analysis of the Fasti is complicated by the poem's really or notionally incomplete state, and by evidence that the poet's plan changed while he composed it, and also by uncertainties concerning his Callimachean and Ennian models. But even these factors, I will argue, are creatively implicated in the Lucretian structure of Ovid's calendar.

To begin with some obvious points. Like Lucretius' poem and Callimachus' Hymns, the Fasti is organized as a sequence of three paired elements. ${ }^{33}$ The first two books are paired because their respective months, January and February, are the two that were added to Romulus' original, ten-month year. ${ }^{34}$ The next two books deal with months, March and April, that are named for two divinities, Mars and Venus (Aphrodite), who form a natural pair in terms of Homeric mythology, Empedoclean philosophy, and Julian dynastic propaganda. In Ovid's hands, they also provide the occasion for a sustained meditation on generic decorum: book 3 is occupied in no small part with the poet's concern that the month of the war-god is too weighty a subject for his elegiacs; while part of the work of book 4 is to repair, under the auspices of the consummately elegiac Venus, the breach of generic decorum that had taken place in the previous book. The last two books, on May and June, are also a thematic pair linked through etymology: May is the month of the elders, the maiores, while June belongs to the youngsters, the iuniores. Thus this aspect of Ovid's general plan - three groups of two books each - remains clear.

The six books of Fasti share a further element with those of DRN when viewed, in this case, as an Ennian hexad. Both Ovid's and Lucretius poems fall clearly into halves, or triads. This much is indicated by the device of "proems in the middle," which are of course a feature of many poems and poetry collections from Hellenistic times onwards. Because the device is so widespread, it may be difficult to attribute Ovid's use of it here to a more extensive Lucretian program. Nevertheless, I think there is good reason to 
believe that he had Lucretius specifically in mind..$^{35}$ The "proem in the middle" is generally hard to miss. But Lucretius' contribution to this tradition went unappreciated until very recently - until, in fact, Conte explained in these terms a feature of Lucretius' poem that had traditionally been ascribed either to poor workmanship or to the poem's unfinished state. The opening of DRN 4 repeats, nearly verbatim, about 25 lines from book $1{ }^{36}$ The opening of book 4 of the Fasti, like all other books of the poem,is replete with programmatic gestures of various kinds, but nothing on the order that we find in most of Conte's examples. Like book 4 of De rerum natura, however, it does repeat, nearly verbatim, a passage from book $1{ }^{37}$ Here we are dealing with only a couplet, so that the gesture of repetition is made with great tact. But the Fasti repeats a couplet from the very opening lines of its first book. This change makes the "proem in the middle" motif that much clearer as an allusion to Lucretius in particular.

It is also significant, I would suggest, that the proem to Fasti 4 alludes with great clarity to the opening of Lucretius' poem. The first word of each book is alma; in both cases alma is the epithet of Venus; each address to Venus is in the context of a cletic hymn in which the goddess is enlisted as the poet's ally; and so forth. The sophistication whereby Ovid alludes to Lucretius' initial proem by way of fashioning a "proem in the middle" is typical of Ovid. He undertakes the converse operation at the beginning of the Amores, where the opening of book 1 alludes both the opening of the Aeneid - the final poem of Vergil's career - and to the beginning of Eclogue 6 - the "proem in the middle" found in Vergil's first major work. And of course, here in Fasti 4 Ovid alludes not just to Lucretius 1 and 4 , but to the beginning of Horace, Odes 4 (another fourth book devoted to Venus) and to himself at the beginning of the Amores, as well. ${ }^{38} \mathrm{In}$ addition, the central, Empedoclean image of Lucretius' "Hymn to Venus," that of the goddess of love subduing the god of war, speaks very directly to the position of Ovid's allusion in the center not just of his poem, but of its central pair of books, at the very point where the month of Venus follows (and so replaces) the month of Mars.

Here it may also be worth considering what Lucretius changes when he repeats in book 4 what he had said in book 1 . Stratis Kyriakidis correctly notes that the lines that Lucretius repeats are part of a digression that is "a distinct and complete unit of thought." The digression begins as follows:

Nunc age, quod super est, cognosce et clarius audi. nec me animi fallit quam sint obscura; sed acri percussit thyrso laudis spes magna meum cor et simul incussit suavem mi in pectus amorem Musarum, quo nunc instinctus mente vigenti 925 avia Pieridum peragro loca nullius ante trita solo. iuvat integros accedere fontis atque haurire

But in book 4, Lucretius omits the first five lines and begins abruptly with the words avia Pieridum.... What is the effect of this omission? To quote Kyriakidis,

The five lines opening the paragraph in Book 1 inevitably draw the reader's attention. There, the poet acted not only under the influence of his quest for renown, but also because of his love for the Muses.... The amor for the Muses put the poet under their spell and they became his driving force. The exclusion, however, of these five lines from the beginning of Book 4 drastically alters the context of the remainder: Lucretius now has a free hand to form his own poetry by not being instinctus any more. ${ }^{39}$ 
The significance of these observations for interpreters of Ovid should be obvious. Lucretius' repetition, in effect, involves a renuntiatio amoris. Ovid's allusion to Lucretius' repetition restores love, a theme that the poet had "abandoned" in the first three books of the Fasti, to its former preeminence while placing Venus herself in the position of Ovid's Muse.

So there is a case, I think, for believing that the six-book structure of De rerum natura influenced that of the Fasti. But since there is also reason to suspect that Lucretius based his structure on features of Callimachus' Hymns and of Ennius' Annales, an obvious question arises. Does Ovid's version of this structure indicate any debt to Callimachus and Ennius as well as Lucretius?

This should be a promising line of investigation, since Ovid's links to both authors are many. And in fact, the case that Ovid does have both Callimachus and Ennius in mind as models both for Lucretius' poem and for his own, is clear. The traces of this indebtedness are presented with great sophistication, as is typical of Ovid, and in a way that, to my mind, serves to clinch the argument. The sophistication has to do with the fact that the Fasti, in its relationship with the Metamorphoses, is but one half of a pair of poems that challenge conventional notions of poetic unity. So it is not surprising if Ovid draws his formal models into the field of indeterminacy that these twin poems create between them.

Ovid's general debt to Callimachus in the Fasti is widely acknowledged. Understandably, this debt is most often referred to the subgenre of aetiological elegy and so to the Aetia. ${ }^{40}$ But the Hymns were also influential, not only in the Fasti but throughout Ovid's career. ${ }^{41}$ Ovid's detailed familiarity with the Hymns and his frequent use (and reuse) of specific passages in the Fasti and other works makes it virtually certain that he was aware of the structure of Callimachus' hymn-book. It remains true, as was noted above, that it is the Aetia and not the Hymns that is the chief conceptual model of Ovid's poem. But the Aetia is a poem (or collection of poems) in four books, while the Hymns are a collection of six poems. In light of Ovid's demonstrated familiarity with this collection, it is difficult to imagine that he was unaware that the structure of Fasti 1-6 so closely resembles the arrangement of the Hymns.

With that we may return to Ennius, and so to another problem that involves "two poems," or rather, two versions of the same poem. A number of scholars have embraced the notion that the structure of the Metamorphoses is based on that of the Annales. But this idea assumes that Ovid's fifteen books of Metamorphoses follow the structure of a fifteen-book edition of the Annales. ${ }^{42}$ The final, fifteenth book of this version will have dealt with the Ambracian campaigns of Ennius' patron, Fulvius Nobilior; and it may have concluded with Fulvius' transferring the cult of Hercules of the Muses to Rome as part of his triumph. ${ }^{43}$ In such a design, Fulvius' military and cultic achievement will have closed the ring opened in book 1 when Ennius replaced Roman Camenae with Greek Muses. What is more, here as elsewhere, the Metamorphoses and the Fasti demand that we read them as an ensemble. The final episode of Fasti 6 (and so of the poem as we have it) celebrates the cult of Hercules of the Muses, the very cult that Fulvius Nobilior brought to Rome, and so may very well allude to the final episode of Annales 15. All of this suggests that both the Fasti and the Met regard the Annales as a poem in fifteen, not eighteen, books. ${ }^{44}$ If so, the case that the six books of the Fasti are in any sense an Ennian hexad looks difficult to sustain, and Ovid's treatment of the Annales would thus seem to differ from that of Lucretius in a crucial respect. But there 
may be a relationship among all these poems after all. To see it, we have only to think a bit harder about Ovid's stance towards Ennius.

It makes sense to assume that the fifteen-book structure of the Metamorphoses presupposes an awareness of a similarly structured version of the Annales, and that Ovid's purpose in alluding to this structure was to trump Ennius' universalizing ambitions. Ennius composed a poem about the history of Rome from its beginnings down to his own day; Ovid outdid him by writing one about all of time from the beginning of the universe down to his own day. Viewed through this lens, the fifteenbook structure of both poems connotes completeness, permanence, stability, and so forth. And indeed, the end of the Metamorphoses emphasizes these properties. ${ }^{45}$ Ovid's own exile poetry, however, forces us to regard any claims made in the Metamorphoses with skepticism. To cite only the most explicit piece of revisionism, Tristia 1.7 completely undermines the claim that the Metamorphoses ever attained its perfect form. This is an argument has been made very effectively by Stephen Hinds. ${ }^{46}$

31 Without going into great detail, let me just suggest that the structural relationship that Ovid creates between his Metamorphoses and Ennius' Annales may be read as looking forward to the revisionism of the exile poetry; for, as we know, the fifteen-book structure of the Annales was not stable. The Annales evidently remained in this form only a few years before morphing into an eighteen-book poem; and this later version of the Annales may be as important to Ovid's design of a fifteen-book Metamorphoses as was the earlier version. The Metamorphoses alludes to the fifteen books of Annales as if to a fixed account of all of Roman time. In its own fifteen-book structure, the Metamorphoses invites comparison with Ennius' poem, which it surpasses in scope even as it usurps the outward form of permanence and fixity that Ennius had given his poem. But that design proved not to be fixed: in order to cover all of Roman time, Ennius eventually had to add three more books to his fifteen-book edifice. Of course, neither was the Metamorphoses a fixed structure: that is among the main points developed in Tr. 1.7, which represents a characteristically exilic perspective on Ovid's masterpiece.

Recent criticism has emphasized that the Fasti, too, is an exile poem. ${ }^{47}$ It would make sense if it, too, cast doubt in some way on the claims to immutability that Ovid registers when he concludes his fifteen books of Metamorphoses. I would submit that the poem's six-book structure does just that. It may be that the appearance of Hercules Musarum at the end of Fasti 6 alludes to the end of Annales 15; but if so, we can hardly regard this agreement as a definitive statement of closure. ${ }^{48}$ Rather, we have to admit that the end of the Fasti (as we have it) alludes to a passage that was once, apparently, the end of the Annales, but that was eventually replaced when Ennius added three books to what had been fifteen. This is perhaps a very appropriate gesture to make at the "end" of a poem that should really not end until another six books have been written; all the more so in a poem whose "end" alludes to the final episode of an Annales in fifteen books, but whose six-book structure derives, by way of Lucretius, from an Annales in eighteen books.

33 More could be said, but the key point is simple: Ovid's references in the Metamorphoses and in the Fasti to the Annales as a poem in fifteen books, look very much as if they were part of a larger thematic complex whereby images of stability are re-imagined as proof that all is in flux. Under these circumstances, it seems to me characteristic that the end of the Fasti might allude to the end of Annales 15, while the entire poem presented itself as an Ennian/Lucretian hexad. 

I think it is worth our time to consider them is that Lucretius' subject matter tends to place him somewhat outside the mainstream of research in Latin poetry. This is perhaps particularly true at a time when our sources for and knowledge about the Roman reception of Epicureanism in the first century are expanding, much more quickly than is the case for our knowledge of Roman poetry in general. What I have tried to do is to identify a factor that might allow us to understand Lucretius' place in the history of Roman poetry qua poetry. My hope is that the points I have raised, however provisionally, may become a provocation to further research in this area.

\section{BIBLIOGRAPHY}

Aicher, Peter J. 1992. “Lucretian revisions of Homer.” CJ 87: 139-58.

Andreoni, Emanuela, "Sul contrasto ideologico fra il De re publica di Cicerone e il poema di Lucrezio (La genesi della società civile)," Studi di poesia latina in onore di Antonio Traglia (Rome 1979) 281-321.

Bailey, Cyril. 1947. Lucretius, De rerum natura libri sex. Ed. with prolegomena, critical apparatus, translation, and commentary. Oxford

Barchiesi, Alessandro. 1991. "Discordant Muses." PCPS 37: 1-21.

. The Poet and the Prince: Ovid and Augustan Discourse. Berkeley. [Translation of Il poeta e il principe: Ovidio e il discorso augusteo. Rome.] . 1997b. “Endgames: Ovid's Metamorphoses 15 and Fasti 6." In Classical Closure: Reading the End in Greek and Latin Literature. Ed. Deborah H. Roberts, Francis M. Dunn, and Don Fowler. Princeton.

Barchiesi, Marino. 1962. Nevio epico. Padua.

Braun, Ludwig. 1981. “Kompositionskunst in Ovids Fasti.” ANRW 1.31.4: 2344-83.

Brown, Robert D. 1982. "Lucretius and Callimachus." Illinois Classical Studies 7: 77-97.

Bulloch, Anthony. 1985. Callimachus: The Fifth Hymn. Cambridge Classical Texts and Commentaries 26. Cambridge.

Clausen, Wendell. 1964. "Callimachus and Latin Poetry.” GRBS 5: 181-96.

Conte, Gian Biagio. 1992. "Proems in the Middle." In Beginnings in Classical Literature. Ed. Francis M. Dunn and Thomas Cole. Yale Classical Studies 29: 147-59.

Cornell, T. J. 1986. “The Annals of Quintus Ennius.” Review of Skutsch 1985. JRS 76: 244-50.

Courtney, Edward. 1993. The Fragmentary Latin Poets. Oxford.

Dancy, Russell. 2003. "Xenocrates." In The Stanford Encyclopedia of Philosophy. Fall 2003 edition. Ed. Edward N. Zalta. URL = http://plato.stanford.edu/archives/fall2003/entries/xenocrates/

Donohue, Harold. 1993. The Song of the Swan: Lucretius and the Influence of Callimachus. Lanham, MD. 
Fabre-Serris, Jacqueline. 1995. Mythe et poésie dans les Metamorphoses d'Ovide. Fonctions et significations de la mythologie dans la Rome augustéenne. Études et commentaires 104. Paris.

Fantham, Elaine. 1985. "Ovid, Germanicus, and the Composition of the Fasti." PLLS 5: 243-81. 1998. Ovid: Fasti, Book IV. Cambridge Greek and Latin Classics. Cambridge.

Farrell, Joseph. 1991. Vergil's Georgics and the Traditions of Ancient Epic: The Art of Allusion in Literary History. New York.

2004-2005. "Precincts of Venus: Towards a Prehistory of Ovidian Genre." In Aetas Ovidiana? Ed. Damien Nelis. Hermathena 177 \& 178. $28-69$.

2007. "The Architecture of the De rerum natura." In The Cambridge Companion to Lucretius. Ed. Stuart Gillespie and Philip Hardie. Cambridge. 76-91.

Feeney, D. C. 1999. "Mea Tempora: Patterning of Time in the Metamorphoses." In Ovidian Transformations: Essays on Ovid's "Metamorphoses" and Its Reception. Ed. Philip Hardie, Alessandro Barchiesi, and Stephen Hinds. Cambridge.

Floratos, C. 1960. “Veneralia.” Hermes 88: 197-216.

Gale, Monica. 1994a. "Lucretius 4.1-25 and the Proems of the De rerum natura." PCPS 40:1-17. 1994b. Myth and Poetry in Lucretius. Cambridge.

2007: "Lucretius and Previous Poetic Traditions." In The Cambridge Companion to Lucretius. Ed. Stuart Gillespie and Philip Hardie. Cambridge. 59-75.

Giesecke, Annette Lucia. 2000: Atoms, Ataraxy, and Allusion. Cross-Generic Imitation of the De rerum natura in Early Augustan Poetry. Spudasmata 76. Hildesheim.

Goldberg, Sander M. 1995. Epic in Republican Rome. New York.

Gratwick, A. S. 1982: “Ennius' Annales." In The Cambridge Companion to Classical Literature. Ed. P. E. Easterling and E. J. Kenney. Vol. 2: Latin Literature. Ed. E. J. Kenney and W. V. Clausen. Cambridge. 6-76.

Hardie, P. R. 2004. “Ovidian middles.” In Middles in Latin Poetry. Ed. S. Kyriakidis. Bari. 151-182. 2008. “Horace’s Sublime Yearnings: Lucretian Ironies.” PLLS 13: 119-172.

Hinds, S. E. 1985. “Booking the Return Trip: Ovid and Tristia 1.” PCPS 31: 13-32. 1992. “Arma in Ovid's Fasti." In Reconsidering Ovid's Fasti. Ed. John F. Miller. Arethusa 25: 81-149.

Hofmann, Heinz. 1985. “Ovid's Metamorphoses: carmen perpetuum, carmen deductum.” PLLS 5: 22341.

Hopkinson, N. 1984. Callimachus: Hymn to Demeter. Cambridge Classical Texts and Commentaries 27. Cambridge.

Hutchinson, G. O. 2001. “The Date of De Rerum Natura.” CQ 51:150-162.

Jocelyn, H. D. 1972. “The Poems of Quintus Ennius.” ANRW 1.2: 987-1026.

Johnson, William A. 2004. Bookrolls and Scribes in Oxyrhynchus. Toronto.

Kenney, E. J. 1970. “Doctus Lucretius.” Mnemosyne 23: 366-92.

1977. Lucretius. Greece \& Rome New Surveys in the Classics, 11. Oxford.

Kenyon, Frederic G. 1951. Books and Readers in Ancient Greece and Rome. $2 \mathrm{~d}$ ed. Oxford. 
Kyriakidis, Stratis. 2006. “Lucretius' DRN 1.926-50 and the Proem to Book 4. CQ 56: 606-10.

Maltby, Robert. 2002. Tibullus, Elegies: Text, Introduction, and Commentary. Cambridge.

Mariotti, Scevola. 1985. Livio Andronico e la traduzione artistica. 2d. ed. Urbino.

Miller, John H. 1982. "Callimachus and the Augustan Aetiological Elegy.” ANRW 2.30.1:371-417.

1991. Ovid's Elegiac Festivals: Studies in the Fasti. Frankfurt.

Morgan, Llewelyn. 1999. Patterns of Redemption in Virgil's Georgics. Cambridge.

Murgatroyd, Paul. 1994. Tibullus, Elegies II. Edited with introduction and commentary. Oxford.

Newlands, Carole. 1995. Playing with Time. Ovid and the Fasti. Ithaca.

Pfeiffer, Rudolf. 1953. Callimachus. Vol. 2. Hymni et epigrammata. Oxford.

Powell, J. U. 1925. Collectanea Alexandrina. Oxford. Rpt. Chicago 1981.

Santirocco, Matthew. 1986. Unity and Design in Horace's Odes. Chapel Hill.

Schiesaro, Alessandro. 1994. "The Palingenesis of De Rerum Natura.” PCPS 40: 81-107.

Schmidt, E. A. 1979. “Das Problem des Catullbuches.” Philologus 123: 216-231.

Schubart, Wilhelm. 1921. Das alte Ägypten und seine Papyrus. Berlin.

Sedley David. 1998. Lucretius and the Transformation of Greek Wisdom. Cambridge.

Skutsch, Otto. 1944/1968. “Enniana I.” CQ 38: 79-86. Rpt. in Studia Enniana. London. 18-29.

1985. The Annals of Quintus Ennius. Oxford.

Thomas, R. F. 1985. "From Recusatio to Commitment: The Evolution of the Virgilian Program." PLLS 5: 61-73.

Trappes-Lomax, John. 2006. “Ovid, Tristia 2.549: How Many Books of Fasti did Ovid Write?” CQ 56: 631-33.

Vahlen, Johannes. 1903. Ennianae Poiesis Reliquiae. 2d ed. Leipzig.

Waszink, J. H. 1979. Opuscula Selecta. Leiden.

Williams, Frederick J. 1978. Callimachus, Hymn to Apollo: A Commentary. Oxford.

Zetzel, James E. G. 1998. "De re publica and De rerum natura." In Style and Tradition: Studies in Honor of Wendell Clausen. Ed. Peter Knox and Clive Foss. Stuttgart and Leipzig. 230-47.

\section{APPENDIXES}

\section{Appendix A. Number and length of books of De rerum natura.}

$D R N$ is the earliest surviving Latin poem that treats the book-roll as a unit of composition. ${ }^{49}$ This is a point that deserves more consideration than it normally receives. When the book-roll is regarded as a structural unit, one of the first decisions that a poet will have to make is how long each one should be. Because poets who wrote after Lucretius generally limited individual books to well under a thousand lines, the 
average Lucretian book of about 1200 lines looks rather bulky. It may even appear to some critics that the length of his books, and therefore perhaps their number as well, were not matters of artistic choice to Lucretius, but instead the result of simply filling up book-rolls until the requirements of the argument had been satisfied. But if we examine the most relevant Greek and especially Roman precedents, the story looks somewhat different.

Any idea that the maximum capacity of a papyrus roll determined the maximum length of its literary contents has to be abandoned. It used to be commonly assumed that an individual papyrus roll could hold no more poetry than the average length of a tragedy or a book of epic. ${ }^{50}$ Now careful reconstruction of fragmentary books suggests that very lengthy poetic books were not as rare as was once believed. ${ }^{51}$ In particular, poems like Livius' Odusia and Naevius' Bellum Poenicum started out as continuous compositions and were only later divided by editors into separate books. ${ }^{52}$ They may have been contained on one or only a few papyrus rolls, which will have been very long indeed..$^{53}$ For Ennius' Annales, which was divided into separate books by the author's own design, Vahlen supposed that the average book must have been between 1500 and 1800 lines. ${ }^{54}$ Otto Skutsch thought this estimate too conservative (1985: 369). ${ }^{55}$ But the length of DRN 5, at 1457 lines the longest book of Lucretius' poem, is below even Vahlen's lower limit. So it seems likely that corpora of early epic poetry in Latin would have looked Cyclopean in comparison to $D R N$, whether in whole or in terms of individual books.

All of this being so, Lucretius' decision in favor of books averaging about 1200 lines must have been carefully considered. It may represent a step in the direction of what later became a standard average book-length of about 800 lines for Latin hexameter poetry, although it might be more informative to assess Lucretius' decision in light of available models rather than the practice of later poets. It seems clear that Lucretius found the average length of an Ennian book longer than what he wanted for his own poem. In Hellenistic poetry, however, the situation is different. Our best information about Hellenistic epic comes from Apollonius, whom we cannot necessarily regard as typical. But it is the case that the average book-length of the Argonautica is 1459 longer than that of $D R N$, but comparable. Also comparable is the degree of variation between the shortest and longest books: book 4 of the Argonautica is 138\% as long as book 2, and book 5 of the $D R N$ is $133 \%$ the length of book 3 . So it is possible that Lucretius was aware of certain principles loosely exemplified by Apollonius and perhaps by others in the construction of multi-book poetic corpora. Another factor may be the length of single Hellenistic poetry books, such as Aratus' Phaenomena, which runs to 1154 lines. It therefore seems likely that Lucretius rejected the parameters concerning book-length that prevailed in earlier Latin poetry in favor of the norms observed by Hellenistic Greek poets.

\section{Appendix B. Collections of six before and after Lucretius}

Relatively few works of Greek or Latin literature are structured as collections of six. Of those that are so structured, a few show structural similarities either to Callimachus' Hymns (three successive pairs of adjacent poems or books) or to an Ennian hexad (two successive triads of poems of books), but apart from Lucretius' DRN, Ovid's Fasti is the 
only poem I have found that combines both of these features and contains clear traces of indebtedness to Callimachus, Ennius, and Lucretius. In this appendix I briefly characterize the background in order that the connections among Callimachus, Ennius, Lucretius, and Ovid might stand out more clearly.

Lucretius described his task as Graiorum obscura reperta...inlustrare Latinis uersibus (1.13637). He is speaking mainly about Greek philosophy, and about Epicurus in particular. Despite generations of doubt, it now seems likely that the general form of Lucretius' argument along with some aspects of his poem's structure descends ultimately from Epicurus' On nature. That work extended to 37 books (Diog. Laert. 10.27), and in David Sedley's argument concerning Lucretius' dependence upon it there is little to suggest that the six-book structure of his poem is to be numbered among his debts to the master. ${ }^{56}$ But if we look for any Greek philosophical work in six books that might have served Lucretius as a model, the fact is that few candidates present themselves. According to the lists found in Diogenes Laertius, several corpora of philosophical prose are structured in this way. ${ }^{57}$ These are all Academic, Peripatetic, or Stoic philosophers, which hardly recommends their works as models for Lucretius; nor do the titles given by Diogenes Laertius suggest much relevance to his aims. ${ }^{58}$

In other prose genres as well, six-book corpora are uncommon. Among longer works, for instance, Polybius' Histories are regarded as exhibiting a hexadic structure, but it would be difficult to identify any more detailed correspondence between his work and the DRN.

In Greek poetry obvious models are equally scarce. The Alexandrian edition of Alcman evidently ran to six books. ${ }^{59}$ If it was like other Hellenistic editions of archaic poetry, it was organized by meter and will have provided little inspiration for Lucretius. The Hellenistic edition of Homer might be a different matter if, as I have suggested, Lucretius viewed his "hexad" as the fourth element that the Annales lacked in order to make a fully Homeric epic in twenty-four books. Hellenistic epic may have influenced Lucretius in this regard, but it is even more difficult to posit a close structural relationship between $D R N$ and any known Hellenistic epic because the remains of any hypothetically relevant works are too scanty to provide evidence sufficient even to form reasonable hypotheses. ${ }^{60}$ There is, however, little evidence for any direct appeal on Lucretius' part to either of the Homeric poems as a structural model. ${ }^{61}$

Besides epic, the most prominent body of Greek poetry that might have provided Lucretius with a structural model would be tragedy. The possibility that the trilogy structure of tragic performances might have inspired Lucretius gains some apparent support from the prominence of the Iphigeneia (or Iphianassa) passage in book 1 . This passage might encourage one to look to Aeschylus' Oresteia, the definitive tragic trilogy,as a model for Lucretius. But again the search for supporting evidence in Lucretius' text proves to be disappointing.

In Latin literature the possibilities are fewer still. To my knowledge, the only works of poetry written before Lucretius that circulated in a corpus of six books were Terence's comedies. ${ }^{62}$ This is hardly an obvious model for $D R N$, but when parallels are so scarce we should be slow to disregard a six-book corpus notable for its prologues, which impose a definite linear structure (chronological, in this case) on the six individual libri while simultaneously allowing the poet to raise a number of self-reflexive and metapoetic issues, as the Lucretian proemia also do. But while a linear structure is 
present, neither of the other characteristic substructures of the DRN - the simultaneous groupings of books into three pairs and two triads - informs Terence's comedies.

As for influence, six-book corpora or single-book collections of six poems even after Lucretius remain few and far between. ${ }^{63}$ Among them are the second book of Tibullus' elegies, the first book of Statius' Silvae, and the elegy-book of Lygdamus. I would also just mention here a pair of poem cycles, Horace's "Roman odes" and the epigrams of Sulpicia. Tibullus book 2 shows some congruity with the design of DRN, particularly in its triadic $(2+2+2)$ structure. It seems likely, however, that this aspect of Tibullus' design is owed directly to Callimachus rather than to Lucretius. ${ }^{64}$ In addition, the internal structure of Tibullus 2 is much more asymmetrical than that of Lucretius with respect to the length of individual poems or books. As for Lygdamus and Sulpicia, whose poetry is transmitted to us as part of the corpus Tibullianum, it seems likely that they are simply following the lead of Tibullus when they fashion collections of six poems, without thinking about his or any other of the few available models. ${ }^{65}$ Horace could also be thinking of Tibullus when he opens the "Roman odes" with the command favete linguis (cf. Tib. 2.1.1, 2.2.2). He could also be thinking of Lucretius at certain points within these poems, but most analyses find quite different patterns in them than are found in $D R N .{ }^{66}$ Finally, regarding Statius, the structure of Silvae 1, while impressively strict in certain ways, is, again, quite asymmetrical in a way that differs sharply from Lucretius (even more sharply than does Tibullus). ${ }^{67}$ In addition, the internal structure of Statius' book seems to owe little to Lucretius or indeed to any of the other antecedents that we have examined.

\section{Appendix C. Lucretius and the structure of Cicero's De republica.}

It is perhaps surprising to realize, but one of the closest similarities in structure that can be found between DRN and any other work involves Cicero's treatise De republica. The point has been made by J. E. G. Zetzel, who notes that like DRN, DRP is in six books that, like those of $D R N$, are presented as three pairs. ${ }^{68}$ Within these similar structures, the two works move as it were in opposite directions. Whereas Lucretius' poem moves from the simplest to the most complex things in the universe Cicero moves inversely from macrocosm to microcosm, beginning with a consideration of different forms of government and concluding with the performance of individuals. This formal inversion, Zetzel suggests, corresponds to a pronounced difference in philosophical and political perspective. For Lucretius, the ultimate lesson to be learned by studying the nature of the universe is detachment, not political engagement. This attitude is diametrically opposed to that of Cicero, for whom the statesman's calling is the highest imaginable. The pronounced differences between these two outlooks are clearly reflected in the conclusions of the two works. For Lucretius, the concluding episode of the "Plague of Athens" may be a kind of test of the reader's ability to contemplate distressing subjects with detachment. For Cicero, the image of a divinely ordered universe revealed in the Somnium Scipionis is an call to virtuous engagement.

I find Zetzel's argument entirely convincing. In relating it to the arguments of this paper, it goes without saying that Cicero adapted the structure that Lucretius' poem to his own purpose, without any interest in whether Lucretius had adapted this scheme 
from Callimachus. On the other hand, Zetzel is surely correct to find that Ennius is implicated in Cicero's engagement with Lucretius. ${ }^{69}$ Ovid on the other hand, while he is interested in both Callimachus and Ennius, shows no awareness of or interest in Cicero's imitation and rebuttal of Lucretius.

\section{NOTES}

1. For detailed analysis of these aspects of the poem's structure see Farrell 2007, with further references. The present paper, which explores some of the implications of the earlier one, was read in a preliminary version on July 25, 2005 at a workshop held in Corpus Christi College, Oxford. My thanks to the organizers of the workshop and to my fellow participants for the stimulus of the occasion and for their discussion and encouragement. Additional thanks to Philip Hardie for his generous comments on the penultimate draft of this paper, and to the editor and anonymous referee of Dictynna for their suggestions.

2. If we assume that the total length of DRN would have been the same regardless of the number of books that Lucretius settled on, then average book-length may have been a contributing factor to his choosing a six-book structure. I discuss some aspects of this choice in Appendix A.

3. I briefly survey the surrounding landscape of six-element literary structures in Appendix B.

4. There is in addition a work of Latin prose, Cicero's De republica, that resembles DRN in its deployment of a six-book structure. I discuss this resemblance in Appendix C.

5. Pfeiffer 1953: liii. The order of the medieval mss agrees with that of papyrus finds, and so definitely goes back to antiquity. Most have followed in attributing it to Callimachus. The arrangement of the Hymns has been elucidated by Hopkinson 1984: 13-17, with primary focus on the pairing of 5 and 6 . Here I summarize the main points of his account that pertain to the collection as a whole.

6. On Lucretius' proems see Gale 1994a.

7. The problem is well handled by Gale $1994 \mathrm{~b}$.

8. Farrell 2007: 82 with note 17.

9. Farrell 2007: 83.

10. DRN 1.117. For the Ennian passage that Lucretius cites see Skutsch 1985: 154-157.

11. Livius' Odusia originally lacked book divisions either because Homer's Odyssey itself did not yet have them, or else if it did, Livius ignored them. In either case, all fragments attributed to a specific book of Livius' translation scan as hexameters, and must therefore belong to a postEnnian revision of the poem: see Mariotti 1985: 55-59. In effect, then, any distinctive influence emanating from the structure of Livius' Odusia (as distinct from either of the Homeric poems) will be impossible to detect. It is possible, however, as one of the journal's referees helpfully suggests, that the textual history of Naevius' epic may have influenced Lucretius' plan. The division of the Bellum Poenicum into seven books was the work not of Naevius but of the grammarian C. Octavius Lampadio (Suet. De gramm. 2). But, as the referee points out, Lampadio's floruit precedes Lucretius, and in Varro's Rome both the continuous and the seven-book version of Naevius' poem circulate (Barchiesi 1962: 12-13 and 268 n. 1246). One cannot say just how or why Lampadio settled on the number seven, rather than, say, six; one might hypothesize that Lampadio's choice of seven reflects his analysis of the poem into $1+6$ books - as a preliminary book followed by six containing the main business of the narrative, for instance. Of course, the distribution of fragments attributed to specific books and the reconstruction of the poem make such hypotheses exceedingly speculative. The symbolic importance of numbers like six and seven may also be in play-perhaps even more in the case of Ennius, because of his Pythagorean tendencies-but I must leave that topic for possible consideration in the future. 
12. Skutsch 1985: 5: "The Annals consisting of eighteen books...are clearly structured in groups of three." Cf. Gratwick 1982: 60.

13. Pliny (NH 7.101) speaks of book 16 as an addition (Q. Ennius...sextum decimum adiecit annalem). Several fragments securely attributed to book $16(1$, perhaps 2,3$)$ speak of the poet's return to this material in his old age after a period of inactivity, and compare the deeds of contemporary warriors to those of the past (5). It is impossible to say exactly how much time passed between the release of books 15 and 16.

14. The most explicit attestation of the Annales as a poem complete in eighteen books comes from the fourth-century grammarian Diomedes (1.484). There is no evidence suggesting that there were ever more than eighteen books.

15. Skutsch 1944/1968: 19-20, 1985: 564; Cornell 1986: 246. There is, however, no direct evidence for this view, which is somewhat impugned by the testimony of Cicero (n. 17 below) and Diomedes (n. 14 above). The main evidence cited in support of it is the fact that we have a higher number of citations of book 16 than we do for all but five other books, much higher than for any other book from 11 to 18; and this circumstance is explained by the tendencies of ancient scholars to cite from the first book of any given work. The comparatively large number of citations from book 16 is curious, but the whole question needs to be thought through more systematically than it has been. In particular, proponents of this view have never explained why the poem, which in its physical form was presumably a collection of eighteen book-rolls each labeled Ennii Annalium liber I etc., would circulate as two distinct corpora of fifteen and three books, and not as a single corpus of eighteen.

16. I intend to return to this topic on another occasion.

17. Lucretius' contemporary Cicero (De prov. cons. 20) refers to Ennius' treatment in the Annales (M. ille Lepidus ...annalium litteris et summi poetae voce laudatus est) of an event in $179 \mathrm{BC}$ that must be placed in book 16 (Skutsch 1985: 572-74) or 17 (Vahlen), without any sense whatsoever that he thinks of the later books as a mere addendum or a separate work.

18. Bailey 1947: 615-22; Skutsch 1985: 147-59.

19. Vahlen 1903: clxxv.

20. Skutsch (1985: 292) makes his fr. 137 (postquam lumina sis oculis bonus Ancus reliquit) the first line of book 3, noting that Verg. Aen. 3 and Silius Pun. 3 also begin with the word postquam (along with Luc. Civ. 6, Stat. Theb. 11), and this seems correct.

21. Another book that may have featured a proem is 6 . The line quis potis ingentis oras evolvere belli? (164 Sk) is securely attested as part of that book, and Skutsch (1985: 328-29) considers it to be the first line both of the book and of a formal proem, largely on the basis of Lucretius' echoing of the passage at DRN 5.1; but Verg. Aen. 9.528, Sil. Pun. 5.421, and Auson. Mosel. 298, also cited by Skutsch, parallel the Ennian line as closely as or even closer than Lucretius, and do not begin books. I would therefore say that the question of whether Ann. 6 began with a formal proem remains open.

22. Book 10 certainly contained, and quite possibly began with the lines insece Musa manu Romanorum induperator / quod quisque in bello gessit cum rege Philippo (322-323 Sk). The first words recall the first line of Livius' Odusia (uirum mihi, Camena, insece uersutum: see Waszink 1979: 95), and as such lend a certain grandeur to this proem.

23. Conte 1992.

24. Morgan 1999: 20-27.

25. In this regard, the placement of Ennius' remarks about Naevius in the seventh book of the Annales may be seen as creating a momentary effect of adventitious parallelism between the structure of Naevius' poem and that of Ennius. As I have noted, Naevius' poem originally circulated as a single, continuous text. Ennius himself was almost certainly dead when the division occurred some time in the mid-second century, so the fact that his Naevius-proem occurs in book 7 of the Annales has nothing to do with Lampadio's division of the Bellum Poenicum 
into seven books. But again, Ennius' design may be less important than a reader's ideas about that design. Someone reading Ennius' comments on Naevius many years after Lampadio's edition had become standard, might have put two and two together and come up with seven, inferring that Ennius' reference to Naevius in the seventh book of his own epic, was a nod to the sevenbook structure of Naevius' poem. Such a reader, especially if he were himself a poet ambitious to establish his own place in the tradition, might have drawn a lesson from Ennius' treatment of Naevius about the way in which principles of structuration could inform one's own efforts to establish a locus standi vis a vis one's predecessors. It may be, then, that some such interpretation of the way in which the seven-book structure of Naevius' poem "influenced" Ennius' decision to organize the Annales by hexads, influenced in turn Lucretius' decision to structure his own poem as a single Ennian hexad.

26. In a more general sense, one may wonder whether the tripartite structure of Annales might have had some influence on Lucretius? Perhaps; but in my view the closer congruency between Lucretius' scheme and that of Callimachus' Hymns would suggest that Callimachus was indeed an independent model.

27. On Ennius as a Hellenistic poet see Gratwick 1982: 63-75; Goldberg 1995: 90-91 is more skeptical. On Ennius' awareness and use of Callimachus see Clausen 1964: 187, Skutsch 1985: 128, Gratwick 1982: 60, Donohue 1993. Jocelyn 1972: 1015 is dismissive.

28. See Kenney 1970, Brown 1982, Giesecke 2000: 4-7, Gale 2007: 7070-72.

29. Discussion in Farrell 1991: 276-98.

30. Thomas 1985; Farrell 1991: 314-32.

31. There is much discussion in the Fasti of the number of months in the year, first ten under Romulus, then twelve after Numa (Fasti 1.27-44, 3.119-54). The poem insists that the number of its books will equal the number of months. As he approaches the end of book 6, Ovid begins his countdown to the end of June (on which see Barchiesi 1994/1997a: 259-71 1997b: 200-7) by observing that only twelve days remain (Fast. 6.725). His manner of expression - iam sex et totidem luces de mense supersunt - teasingly resembles his (later?) claim (Tr. 2.549-50) to have written a twelve-book poem: sex ego Fastorum scripsi totidemque libellos / cumque suo finem mense uolumen habet. (For a different-and unconvincing, in my view - interpretation of this couplet, see Trappes-Lomax 2006.)

32. This situation has changed in the past few years. See in particular Barchiesi 1994/1997a: 177, 259-71; 1997b; Newlands 1995: 6.

33. Braun 1981; cf. Newlands 1995: 16-18.

34. Fasti 1.27-44, 3.119-54.

35. On this relationship see Schiesaro 1994 and Hardie 2004.

36. Conte 1992. The problem of this repetition has been considered anew from the point of view of Epicurean poetics by Kyriakidis 2006. In the next few paragraphs I try to suggest some of the relevance of Kyriakidis' findings to readers of Ovid.

37. Ovid thus follows Lucretius even to the extent of slightly varying himself in repetition. In a context where self-repetition and allusion to a different author are involved, the impact of the gesture is multiplied, raising some intriguing questions about Ovid's allusive artistry.

38. On Fasti 4 and Amores 1 see Hinds 1992: 85-87. On Horace and Ovid see Barchiesi 1994/1997a: 54-57, 268; Fantham 1998: 90-91; Farrell 2004-2005: 53-62.

39. Kyriakidis 2006: 608.

40. Miller 1982 and 1991.

41. Most obviously, the sixth hymn is also laid under contribution for the story of Erisychthon, which Ovid tells at Met. 8.738-878. For a discussion of what specifically Ovid owes to Callimachus and to other sources, see Floratos 1960: 197-216, esp. 128; Williams 1978: 55, 83; Hopkinson 1984: 22-24; Bulloch 1985: 190; Barchiesi 1994/1997a: 22, 129, 182, 194-195, 223-25; Fabre-Serris 1995: 285-89; Fantham 1998: 117. 
42. Hofmann 1985: 223-26, esp. 225.

43. Skutsch 1944/1968: 18-21.

44. Barchiesi 1991: 6-7 and 1994/1997a: 264-71 1997b: 203-7; Feeney 1999: 16-18.

45. Met. 15.871-79.

46. Hinds 1985 .

47. Fantham 1985 is fundamental here.

48. Barchiesi 1994/1997a: 266-71 1997b: 203-7; Newlands 1995: 215-220.

49. Kenney 1977 makes this point.

50. Schubart 1921: 52 gives $10 \mathrm{~m}$. as extreme upper limit for Greek literary texts; Kenyon 1951: 54 gives $35 \mathrm{ft}$. $=10.7 \mathrm{~m}$. By way of comparison, Johnson 2004: 145 calculates the measurements for an existing papyrus roll containing Soph. OT at $8.5 \mathrm{~m}$., and for Eur. Phoen. At $11 \mathrm{~m}$.

51. Johnson 2004: 146-48 cites a copy of Herodotus' first book that measured $22.9 \mathrm{~m}$. - more than twice the length of the longer tragic papyrus mentioned in the previous note - a copy of Philodemus De pietate that measured 23 m., and a single roll containing Hom. Il. 19-22-over 2000 lines - that measured $19 \mathrm{~m}$.

52. On Livius see Mariotti 1985: 55-59. On Naevius see Suetonius gramm. 2.

53. The surviving fragments of Livius' Odusia include translations of passages that span virtually the entire Odyssey of Homer. It is possible that Livius' poem was an abridgement, but even so it must have extended to many thousands of lines. In the case of Naevius' Bellum Poenicum, we know so little that it is virtually impossible to estimate its dimensions with any confidence. Skutsch (1985: 369) assumes that this work extended to about 4000 lines and was contained on a single roll.

54. Vahlen 1903: cxlvi. He is followed by Gratwick 1982: 60, who gives a range of 1000 to 1700 lines.

55. Skutsch (1985: 369), citing Schmidt 1979: 216-31 for estimates for several poetry books that may have extended to several thousand lines apiece.

56. Sedley 1998: 136 presents a comparison between the (probable) contents of Peri physeos 1-15 and DRN 1-6. It is obvious that a fifteen-book corpus could easily be divided into groups of five books, and that Lucretius could have condensed the contents of each pentad into two books; but there is no such correspondence between, say, Peri physeos 1-5 and DRN 1-2. Curiously, on Sedley's analysis it does appear that the contents of DRN 1-2 correspond fairly closely to those of Peri physeos 1-2, while the next two books of DRN similarly parallel books 3-4. But Lucretius handles Epicurus' books 5-15 much differently. DRN 5-6 appear to be based substantially on three books of Peri physeos (11-13), while much of Peri physeos 5-10 has been distributed throughout DRN 2-4. It is not impossible that Lucretius' six-book design is simply a development and refinement of structural ideas latent in Peri physeos, but it is at least as likely that the six-book design derives from another source.

Sedley has also considerably strengthened the case that Lucretius conceived of DRN as an Empedoclean poem (1998: 1-34, 200-204), but apart from important aspects of the opening passage of DRN, there is little evidence that Lucretius regarded Empedocles as a structural model. 57. Among these are works by Euclides, Xenocrates, Aristotle, Theophrastus, Heraclides Lembus, Zeno, Ariston, and Chrysippus of Soli (or Tarsus). In addition, Aristippus may have written six books of diatribes, although it was disputed in antiquity whether he wrote anything (DL 2.84).

58. For example: Xenocrates, as an early director of the Academy, was a figure of some institutional importance, and among the more than seventy titles listed by Diogenes Laertius (4.11-13) are several treatises in six books, including a Peri physeos; but in view of the fact that "nothing whatever of these has survived, even in the form of identifiable quotations in other authors" (Dancy 2003), it seems unlikely that Lucretius will even have known his writings.

59. According to the Suda (A 1289 Adler). 
60. The epic poet Rhianus of Crete composed, among other works, a Messeniaca in at least six books (Powell 1925: 9, FrGH 265). Perhaps Lucretius was influenced by Apollonius' decision to work within a four-book structure, i.e. with a number of books that is a fraction of the twentyfour books into which Hellenistic scholarship divided the Iliad and the Odyssey. Note however that Rhianus and Apollonius may antedate the canonical division of Homer's works into books. In this case, however, it would still be possible for Lucretius, who probably did not know precisely when the standard book divisions of the Homeric epics were finally established, to infer that Rhianus' and Apollonius' epics in six and four books, respectively, were designed as fractions of Homer's twenty-four-book epics.

61. A passage from the proem of DRN $3(18-22)$ closely paraphrases $0 d .6 .42-45$ in a way that might under the right circumstances signal a broader structural congruency; but in this case the numerical correspondences simply do not work. DRN 3 is the last book of the poem's first half; Od. 6 is the last book of the poem's first quarter. This might suggest a scheme by which Lucretius modeled his poem on the first half of the Odyssey (i.e. books 1-12), but I at least cannot envision the next step in such an argument. For an assessment of Lucretius' allusions to Homer see Aicher 1992.

62. Ennius' Satires circulated in a corpus of either four (Ennius qui IV libros saturarum reliquit, Porph. in Hor. Serm. 1.10.46) or six books (haec non ab Apollodoro sed e sexto satirarum Ennii translata sunt omnia, Don. in Ter. Ph. 339); there is at least one fragment from each of the putative six books except book 5 (see Courtney 1993: 7-21), presumably arranged by the poet himself, but we have no definite information on this point.

63. Most of the poetry written in the half-century or so that followed the appearance of DRN shows little evidence of adopting its overall structure. A partial case is that of the second and third books of the Georgics, which, as I have argued elsewhere (Farrell 1991: 169-206), borrow heavily from DRN 5-6 not only verbally, but in subject matter, theme, and tonal movement. Bearing this in mind, one might be tempted to analyze the twelve-book Aeneid as a pair of Ennian/Lucretian hexads, but I see little evidence of such a design.

64. See Murgatroyd 1994: xii and Maltby 2002: 52.

65. Lygdamus' book, like Tibullus 2 , features poems of quite uneven length, but this unevenness seems even more deliberate than in Tibullus' case. The first three poems comprise 28,30 , and 38 lines, respectively, or 96 lines in all; poem 4, the longest of the six, extends to 98 lines, practically the same number comprised by the first three elegies together; poems 5 and 6 have 34 and 64 lines, respectively, or, once again, 98 lines in all. Exact numerical symmetry could be restored by supposing the loss of a single couplet somewhere in poems 1-3. Such things are always possible, and in fact a number of couplets survive only in one branch of the ms tradition. The "garland" of Sulpicia divides readily into halves: passionate devotion is the theme of the first three, while the consequences of perceived rejection dominate the last three. By line numbers as well there is a strictly symmetrical arrangement: $10+8(=18) ; 4 ; 6+6+6(=18)$. Beyond this, it is clear that poems 2 and 3 (the birthday epigrams) and poems 4 and 5 (Sulpicia reproaches Cerinthus for his faithlessness) are paired, while poem 1 introduces the collection and 6 provides it with a quite open conclusion. This arrangement $(1,2+3,4+5,6)$ is thus bipartite, but shows no sign of tripartite division.

66. A in intersting case for Horatian influence has been made by Hardie 2008. The various proposals regarding the structure of the "Roman odes" are conveniently discussed by Santirocco 1986: 113-15.

67. Averages mean little in this collection, where the general impression is one of deliberate variatio and asymmetry. Only two adjacent poems are of similar length (3and 4), and the latter is indeed close to the average length for this book. Every other poem is substantially longer or shorter than the ones that surround it. The figures are 107, 277, 110. 131, 65, and 102 lines (= 792; $\div 6=132$ lines). The first two poems together comprise nearly as many lines (384) as the last four 
(408). The odd-numbered poems are all ecphrases (1, a statue; 3 , a villa; 5 , a bath) while the evennumbered are all occasional (2, an epithalamion; 4, a soteria; 6 , the Kalends of December).

68. Indeed, this aspect of the treatise's structure is, if anything, more obvious than is the case with Lucretius' poem. Cicero begins each of the odd numbered books of $\operatorname{DRP}(1,3,5)$ with a major preface that is clearly intended to introduce each of three pairs of books $(1+2,3+4,5+6)$. The chronological structure of $D R P$ - the work is presented as the record of conversations that took place on the three successive days of the ludi Romani, with each of the conversations occupying two consecutive books - makes the tripartite structure of the treatise very clear indeed. Cicero also, as I have said, reserves major prefaces for only three books, a decision that stresses the tripartite division of his work, whereas Lucretius begins all six books with a formal preface.

69. Zetzel 1998: 233-35; cf. Andreoni 1979. Hutchinson 2001 argues that DRN was not written until 49, after the release of DRP in 51 (Fam. 8.1.4), and casts doubt on whether the words Lucreti poemata at Qfr 2.10.3 (February 54) refer to DRN at all. If he is right on both counts, then the view of the relationship assumed here is obviously wrong. But even if Hutchinson is correct about the date, it is obvious that Cicero was in some sort of contact with Lucretius and that he had access to Lucretius' work when he was just beginning to work on DRP, so that it remains possible that the structure of his dialogue owes something to Lucretius.

\section{ABSTRACTS}

Lucretius' De rerum natura is one of the relatively few corpora of Greek and Roman literature that is structured in six books. It is distinguished as well by features that encourage readers to understand it both as a sequence of two groups of three books $(1+2+3,4+5+6)$ and also as three successive pairs of books $(1+2,3+4,5+6)$. This paper argues that the former organizations scheme derives from the structure of Ennius' Annales and the latter from Callimachus' book of Hynms. It further argues that this Lucretius' union of these two six-element schemes influenced the structure employed by Ovid in the Fasti. An appendix endorses Zetzel's idea that the six-book structure of Cicero's De re publica marks that work as well as a response to Lucretius' poem.

\section{INDEX}

Mots-clés: Lucretius, De rerum natura, Ennius, Annales, Callimachus, Hymns, Ovid, Fasti, Cicero, De re publica, structure

\section{AUTHOR}

\section{JOSEPH FARRELL}

University of Pennsylvania

jfarrell@sas.upenn.edu 